\title{
Redaksjonelt
}

\section{Nye artikler våren 2012}

Acta Didactica Norge er et nasjonalt akademisk forum for fagdidaktisk forsknings- og utviklingsarbeid. Det er nå i sin sjette årgang, og så langt i 2012 har vi gitt ut elleve bidrag fra inn- og utland på norsk, svensk, dansk og engelsk. En del av disse artiklene inngår i to tematiske artikkelgrupper fra konferansen Visions 2011, som ble arrangert ved Universitetet i Oslo i fjor. Den ene artikkelgruppen handler om fagdidaktikk (teaching) og den andre om lærerutdanning (teacher education).

Først ute i år er imidlertid Ragnhild Lund med artikkelen Sing English: Om sangens potensial i engelskoppleringen. Den bruker læreplanene og utvalgte lærebøker for å belyse seg sangens rolle i ungdomstrinnets engelskundervisning i perioden 1885-2008.

Den neste artikkelen, Texter, läsförståelse och läsundervisning i Norge och Sverige - en översikt, er en omfattende review-artikkel der Monica Reichenberg sammenligner norsk og svensk leseforskning. Hun stiller spørsmålet om en av grunnene til at Norge har oppnådd bedre framgang enn Sverige i PISA 2009undersøkelsen, kan være en mer systematisk praktisk og forskningsmessig innsats.

Litteraturdidaktikk er i fokus i Tina Høeghs artikkel Mundtlig fortolkning kreativ praksis i litteratur- og sprogundervisning. Høegh presenterer en tilnærming til litteraturundervisning som bør være av interesse for mange.

Andre fremmedspråk har i Norge lenge slitt med lav interesse og rekruttering, selv om situasjonen har bedret seg betraktelig de siste årene. Et av problemene for fremmedspråkene er at de er usynlige på jobbmarkedet, dvs. at de knapt nevnes i stillingsutlysninger. I sin artikkel Fremmedspråk $i$ norsk arbeidsliv: gapet mellom behov og etterspørsel undersøker Eva Thue Vold og Gerard Doetjes stillingsannonser på finn.no og nav.no og dokumenterer at fremmedspråkene sjelden nevnes, og da kun som et forsiktig ønske. Deres hovedforklaring er at det er så liten tilgang på relevante søkere med kompetanse i fremmedspråk at arbeidsgiverne har gitt opp å etterspørre det. De tror imidlertid at situasjonen vil bedre seg i tiden fremover.

Cecilie Flo Jahreies Learning to teach at the boundaries between university courses and internships, er en analyse av hvordan lærerstudenter opplever møtet mellom teori og skolevirkelighet når de kommer ut i praksis. For å lette overgangen for studentene påpeker Jahreie behovet for bedre samarbeid mellom lærerutdanningsinstitusjonene og de partnerskolene som tar imot studentene.

Den andre artikkelen om lærerutdanning er Visions for Teacher Education Experiences from Finland av Sven-Erik Hansén, Liselott Forsman, Jessica Aspfors og Marina Bendtsen. Selv om forfatterne er oppmerksomme på Finlands gode resultater i PISA-undersøkelsene og de sterke sidene ved finsk 
lærerutdanning, drøfter de nåværende og fremtidige utfordringer og dilemmaer knyttet til organisering. Dette omfatter forholdet mellom generell didaktikk og fagdidaktikk, spenningen mellom forskningsbasert versus praksisorientert undervisning og overgangen fra å være student i lærerutdanning til å arbeide i skolen. Som også Jarheies bidrag viser, er dilemmaene forfatterne beskriver og drøfter minst like relevant for norske forhold.

I artikkelen Norsk og matematikk i et literacy-perspektiv: metabevissthet også for de svake elevene bruker Bodil Kleve og Sylvi Penne eksempler fra norsk og matematikk for å synliggjøre hvordan de to fagene representerer ulike typer utfordringer for elevene. De diskuterer elevers læringsmuligheter i et literacy-perspektiv og fremhever og eksemplifiserer behovet for å utvikle sjangerkunnskap og metaforståelse for å styrke mestringen av faget.

Dag Husebøs bidrag Fagkunnskap og pedagogisk tilnœerming i samspill - En klasseromsstudie av undervisning i faget Religion, livssyn og etikk beskriver et interessant utviklingsprosjekt i religionsdidaktikk hvor formålet var å styrke håndteringen av et religiøst mangfold i skole og lærerutdanning.

Det neste bidraget er om matematikkundervisning. I Matematik behöver också en berättelse - Ledarskap i matematikundervisning beskriver Ann-Louise Petersen resultatene fra et prosjekt med fire lærere og seks klasser på Vg1 som fokuserte på å forbedre matematikklærerenes ledelse av undervisningen. Prosjektet viste seg å resultere i en styrking av elevenes interesse for faget.

Den tiende artikkelen er Multiple perspectives on students' scientific communication \& reasoning in chemistry education av Maik Walpuski, Oliver Tepner, Elke Sumfleth, Sabrina Dollny, Julia Hostenbach, Tobias Pollender. Artikkelen presenterer tre ulike studier av kjemiundervisning tyske skoler.

Cecilie Rønning Haugen anmelder i sitt bidrag boken Gjennomføring av utdanningsreformer i kunnskapssamfunnet av Erling Lars Dale, Nils Gilje og Sølvi Lillejord. Hun mener den gir en oversiktlig og god innføring i kompleksiteten og dilemmaene en står overfor i forbindelse med gjennomføring av utdanningsreformer, og drøfter blant annet forfatternes syn på pedagogikkfagets rolle som dannelses- eller kunnskapsfag.

Vi har en rekke nye artikler til vurdering i redaksjonen, til fagfellevurdering eller til bearbeiding hos forfatterne. Disse vil bli gitt ut i løpet av høsten.

Helt til slutt ønsker jeg som ansvarlig redaktør å takke redaksjonsmedlemmene for deres innsats i vår, og gi en spesiell takk til de mange fagfellevurderene som bidrar og har bidratt til Acta Didactica Norge.

Oslo, 4. juli 2012

Glenn Ole Hellekjær

Ansvarlig redaktør 